\title{
Changes of sugar distribution in different tissues of satsuma mandarine
}

\author{
Jia-Dong $\mathrm{He}^{1}$, Qiang-Sheng $\mathrm{Wu}^{1,2^{*}}$, Mei-Ling Cai ${ }^{1}$ \\ ${ }^{1}$ Institute of Root Biology, College of Horticulture and Gardening, Yangtze University, Jingzhou, Hubei 434025, People's Republic of China. \\ ${ }^{2}$ Department of Chemistry, Faculty of Science, University of Hradec Kralove, Hradec Kralove 50003, Czech Republic.
}

\section{ARTICLE INFO}

Article history:

Received on: 08/06/2016

Revised on: 20/06/2016

Accepted on: 01/07/2016

Available online: 26/08/2016

Key words:

Citrus, Fruit, Glucose,

Sucrose.

\begin{abstract}
The present study analyzed the changes of total sugar, fructose, glucose, and sucrose contents in leaves, roots, and fruits of Citrus unshiu cv Guoqing No. 1 grafted on Poncirus trifoliata in fruit enlargement period (August) and fruit mature period (October). The results showed an increase of glucose, sucrose, and total sugar from enlargement period to mature period. Total sugar content ranked as the trend of fruit pulp $>$ fruit peel $>$ root $>$ distal leaf > proximal leaf. Significantly higher sucrose content was ranked as the trend of fruit pulp > fruit peel > proximal leaf $>$ distal leaf $>$ root in August and fruit pulp $>$ fruit peel $>$ root $>$ proximal leaf $>$ distal leaf in October. Significantly higher fructose content was rated as the trend of fruit pulp $\approx$ fruit peel $>$ distal leaf $>$ root $\approx$ proximal leaf in fruit enlargement period and fruit pulp $>$ fruit peel $\geq$ distal leaf $>$ proximal leaf $>$ root in fruit mature period. Significantly higher glucose content was ranked as the trend of fruit pulp $>$ root $>$ fruit peel $>$ proximal leaf $\approx$ distal leaf in fruit enlargement period and fruit pulp $\geq$ root $>$ fruit peel $>$ proximal leaf $>$ distal leaf in fruit mature period. It concludes that roots recorded relatively lower sugar content than other four tissues, and sugars could transfer from proximal leaf into fruit, which is the center of energy requirement, especially fruit pulp.
\end{abstract}

\section{INTRODUCTION}

Citrus is one of the important fruit trees, whose production is the largest in China among the world. Citrus industry in China also faces many shortcomings, including low yields and poor fruit quality, resulting in a low competition in the international market. Citrus is characterized by fragrant flowers and edible juicy fruit [1].

Fruit quality includes two aspects of external quality and interior quality. External quality consists of fruit shape, size, pericarp smoothness, colour, lustre and peel puffing. Interior quality including edible rate, sugar-acid ratio, flavor, juice sacs, sugar content, and squeeze rate [2]. Meanwhile, flavor quality depends largely on sour and sweet, and the composition, content and proportion of sugar and organic acid are closely related to the fruit flavor quality. Soluble sugar of citrus includes sucrose, glucose and fructose [3]. Sugar

\section{* Corresponding Author}

Prof. Qiang-Sheng Wu, College of Horticulture and Gardening, Yangtze University, Jingzhou, Hubei 434025, China.

E-mail: wuqiangsh@163.com accumulation in fruit citrus had an important influence on flavor formation. These sugars might be originated from the allocation of other tissues. Hence, analyzing sugar changes in different tissues in citrus will illumine the strategy of sugar allocation and fruit flavor quality. The purpose of this study is to assess the changes of sucrose, glucose, and fructose contents in fruit, leaves and roots in fruit enlargement and mature period in citrus tree grown in the field.

\section{MATERIALS AND METHODS}

\subsection{Plant material}

In August (fruit enlargement period) and October (fruit mature period) 2015, we collected the roots, proximal leaves surrounding fruits, distal leaves surrounding fruits, fruit peel, and fruit pulp from a Citrus Orchard of Yangtze University, Jingzhou, China $\left(30^{\circ} 36^{\prime} \mathrm{N}\right.$, and $\left.112^{\circ} 14^{\prime} \mathrm{E}\right)$, where 28 -yr-old Citrus unshiu grafted on Poncirus trifoliata was planted. The collected samples were oven-dried at $75^{\circ} \mathrm{C}$ for $72 \mathrm{~h}$ and sieved by $1-\mathrm{mm}$ mesh. 


\subsection{Experimental design}

The experiment consisted of five treatments (root, proximal leaf surrounding fruits, distal leaf surrounding fruits, fruit peel, and fruit pulp) for each five replicates in a completely random arrangement. Roots, leaves, and fruits were selected from four directions of a satsuma mandarine tree and mixed as a replicate. There were five 28 -yr-old satsuma mandarine (Citrus unshiu grafted on Poncirus trifoliata) trees used here. The growth vigor of satsuma mandarine trees is middle and was randomly selected between the lines in this orchard.

\subsection{Determinations of sugars}

The dry samples of roots, proximal leaves surrounding fruits, distal leaves surrounding fruits, fruit peels, and fruit pulps were incubated with $80 \%$ alcohol for $40 \mathrm{~min}$ at $80^{\circ} \mathrm{C}$, and the contents of sucrose, glucose and fructose were colorimetrically determined by the procedure outlined by Wu et al. [4]. Total sugar was the sum of sucrose, fructose, and glucose.

\subsection{Statistical analysis}

The data (means $\pm \mathrm{SD}, n=5$ ) were analyzed by the ANOVA of SAS (8.1), and the significant differences between the treatments were compared with the Duncan's Multiple Range Test at 0.05 level.

\section{RESULTS}

\subsection{Sucrose content}

As shown in Table 1, the content of sucrose was generally higher in October (fruit mature period) than in August (fruit enlargement period) in each tissue. In fruit enlargement period, significantly higher sucrose content was rated as the trend of fruit pulp > fruit peel > proximal leaf $>$ distal leaf $>$ root. In fruit mature period, significantly higher sucrose content was ranked as the trend of fruit pulp $>$ fruit peel $\geq$ distal leaf $>$ root $>$ proximal leaf.

\subsection{Fructose content}

In fruit enlargement period (August), significantly higher fructose content was rated as the trend of fruit pulp $\approx$ fruit peel $>$ distal leaf $>$ root $\approx$ proximal leaf (Table 2 ). In fruit mature period (October), significantly higher fructose content was ranked as fruit pulp $>$ fruit peel $\geq$ distal leaf $>$ proximal leaf $>$ root in a decrease trend.

\subsection{Glucose content}

The content of glucose was increased from August to October. In fruit enlargement period (August), significantly higher glucose content was ranked as the trend of fruit pulp $>$ root $>$ fruit peel $>$ proximal leaf $\approx$ distal leaf (Table 3 ). In fruit mature period (October), significantly higher glucose content was rated as the trend of fruit pulp $\geq$ root $>$ fruit peel $>$ proximal leaf $>$ distal leaf.

\subsection{Total sugar content}

Total sugar content was increased from fruit enlargement period (August) to fruit mature period (October) (Table 4). In fruit enlargement period and mature period, significantly higher sucrose content was rated as the trend of fruit pulp > fruit peel $>$ root $>$ distal leaf $>$ proximal leaf (Table 4).

Table 1: Change of sucrose content (mg/g DW) in different tissues of satsuma mandarine.

\begin{tabular}{cccccc}
\hline Month & Fruit peel & Fruit pulp & Proximal leaf & Distal leaf & Root \\
\hline August & $25.23 \pm 1.25 \mathrm{~b}$ & $79.20 \pm 3.96 \mathrm{a}$ & $21.96 \pm 1.10 \mathrm{c}$ & $15.33 \pm 0.67 \mathrm{~d}$ & $10.94 \pm 1.02 \mathrm{e}$ \\
October & $52.60 \pm 2.90 \mathrm{~b}$ & $115.11 \pm 9.03 \mathrm{a}$ & $36.04 \pm 1.80 \mathrm{~d}$ & $49.86 \pm 3.78 \mathrm{~b}$ & $37.65 \pm 2.22 \mathrm{c}$ \\
\hline
\end{tabular}

Different letters in the same row mean a significant difference among the tissues $(p<0.05)$. The same below.

Table 2: Change of fructose content (mg/g DW) in different tissues of satsuma mandarine.

\begin{tabular}{|c|c|c|c|c|c|}
\hline Month & Fruit peel & Fruit pulp & Proximal leaf & Distal leaf & Root \\
\hline August & $45.33 \pm 3.06 \mathrm{a}$ & $46.56 \pm 2.27 \mathrm{a}$ & $23.45 \pm 0.63 c$ & $28.58 \pm 0.80 \mathrm{~b}$ & $25.43 \pm 0.35 c$ \\
\hline October & $34.09 \pm 1.51 \mathrm{~b}$ & $69.09 \pm 1.10 \mathrm{a}$ & $25.97 \pm 1.63 \mathrm{~d}$ & $29.52 \pm 1.02 \mathrm{c}$ & $15.28 \pm 0.85 \mathrm{e}$ \\
\hline
\end{tabular}

Table 3: Change of glucose content (mg/g DW) in different tissues of satsuma mandarine.

\begin{tabular}{|c|c|c|c|c|c|}
\hline Month & Fruit peel & Fruit pulp & Proximal leaf & Distal leaf & Root \\
\hline August & $79.62 \pm 0.56 c$ & $117.11 \pm 2.30 \mathrm{a}$ & $52.14 \pm 4.32 \mathrm{~d}$ & $48.81 \pm 3.21 \mathrm{~d}$ & $104.39 \pm 3.85 b$ \\
\hline October & $94.13 \pm 3.24 b$ & $159.28 \pm 8.90 \mathrm{a}$ & $63.28 \pm 5.01 \mathrm{c}$ & $58.08 \pm 2.12 \mathrm{~d}$ & $123.11 \pm 9.79 a$ \\
\hline
\end{tabular}

Table 4: Change of total sugar content (mg/g DW) in different tissues of satsuma mandarine.

\begin{tabular}{|c|c|c|c|c|c|}
\hline Month & Fruit peel & Fruit pulp & Proximal leaf & Distal leaf & Root \\
\hline August & $150.18 \pm 9.51 b$ & $242.87 \pm 5.64 a$ & $97.55 \pm 4.18 \mathrm{e}$ & $112.72 \pm 4.42 \mathrm{~d}$ & $142.10 \pm 6.22 \mathrm{c}$ \\
\hline October & $180.82 \pm 5.29 b$ & $343.48 \pm 8.30 \mathrm{a}$ & $125.29 \pm 5.27 \mathrm{e}$ & $137.46 \pm 3.80 \mathrm{~d}$ & $175.52 \pm 8.83 \mathrm{c}$ \\
\hline
\end{tabular}




\section{DISCUSSION}

This study showed that total sugar, glucose, and sucrose content increased with the fruitful development of the Mandarine satsuma, suggesting that in fruit mature period, citrus tissues would accumulate more total sugar, glucose, and sucrose content for fruit flavor and tissue storage. The accumulation of photosynthates would increase rapidly from enlargement period to mature period [5]. Plant sugar is originated from leaf photosynthesis [6]. In fruit enlargement period, glucose and sucrose content was significantly higher in proximal leaf than in distal leaf. However, in fruit mature period, glucose and sucrose content was higher in distal leaf than in proximal leaf, suggesting that proximal leaf might transfer more sucrose and glucose into fruits according to the principle of proximity.

On the other hand, in fruit, fruit pulp showed significantly higher total sugar, glucose, and sucrose content than fruit peel, suggesting that more sugar was accumulated in fruit pulp for fruit flavor and sweetness. It is well known that the hexose (including glucose and fructose) accumulation had given priority to fruit pulp [7]. The result is in agreement with previous reports in Okitsu satsuma fruit.

It is known that in fruit development, fruit is the center of energy requirement in whole plant, and many photosynthates would allocate into the needful center, namely, fruit. At the same time, roots would be in a disadvantaged place. Hence, in this study, in the five tissues, roots generally showed relatively lower hexose content than other four tissues. In sucrose, glucose, and fructose, roots exhibited a relatively higher glucose than sucrose and fructose. It is documented that root sucrose was cleaved into glucose and fructose by sucrose-cleaved enzymes [8,9]. Therefore, we guess that roots induced phloem-loaded sucrose cleaved more glucose, but not fructose, for root storage.

\section{ACKNOWLEDGEMENTS}

This study was supported by the Plan in Scientific and Technological Innovation Team of Outstanding Young, Hubei Provincial Department of Education (T201604), the Open Fund from the Institute of Root Biology, Yangtze University (R201401), and the Creative Experimental Project of National Undergraduate Students, Yangtze University (2014043).

\section{REFERENCES}

1. Song SY, Lee YK, Kim IJ. Sugar and acid content of Citrus prediction modeling using FT-IR fingerprinting in combination with multivariate statistical analysis. Food Chemistry. 2016; 190:10271032.

2. Khalid S, Malik AU, Saleem BA, Khan AS, Khalid MS, Amin M. Tree age and canopy position affect rind quality, fruit quality and rind nutrient content of 'Kinnow' mandarin (Citrus nobilis Lour $\times$ Citrus deliciosa Tenora). Scientia Horticulturae. 2012; 135:137-144

3. Takagi T, Mukai H, Ichikawa T. Effects of temperature and sugar accumulation in fruits on color development of satsuma mandmrin. Journal of the Japanese Society for Horticultural Science. 1994; 62:725-731.

4. Wu QS, Srivastava AK, Li Y. Effect of mycorrhizal symbiosis on growth behavior and carbohdyrate metabolism of trifoliate orange under different substrate $P$ levels. Journal of Plant Growth Regulation. 2015; 34:495-508.

5. Echeverria E. Burns JK. Vacuolar acid hydrolysis as a physiological mechanism for sucrose breakdown. Plant Physiology. 1989; 90:530533.

6. Zou DG, Zou J, Shen JW, Luo H, Tang J, Li LM. Integrated techniques for improvement of fruit quality and sugar content of satsuma mandarin. South China Fruits. 2011; 40:89-90 (in Chinese with English Abstract).

7. Liu YC, Tao CG, Wei YX, Liu C, Wang XD, Liu WS, Yang YM. Fruit sugar and acid content, variation at different fruit development stages and their relationship with leaf soluble sugar content of blueberry. ScientiaAgricultura Sinica. 2013; 46:4110-4118 (in Chinese with English Abstract).

8. Komatsu A, Takanokura Y, Mongucb T, Qmura M. Akjhama T. Differential expression of three sucrose-phosphate syuthase isoforms during sucrose accumulation in citrus fruits. Plant Science. 1999; 140:169-178.

9. Wu QS, Lou YG, Li Y. Plant growth and tissue sucrose metabolism in the system of trifoliate orange and arbuscular mycorrhizal fungi. Scientia Horticulturae. 2015; 181:189-193.

\section{How to cite this article:}

He JD, Wu QS, Cai ML. Changes of sugar distribution in different tissues of satsuma mandarine. J App Biol Biotech. 2016; 4 (04): 097-099. DOI: 10.7324/JABB.2016.40412 